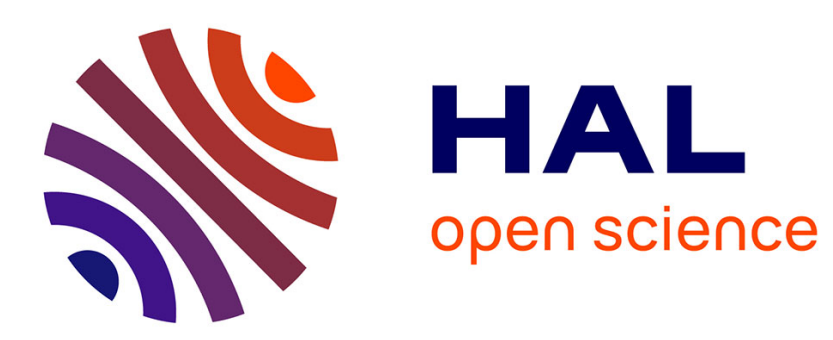

\title{
Biosensor using immobilized Chlorella microalgae for determination of volatile organic compounds.
}

\author{
Martine Naessens, Canh Tran-Minh
}

\section{To cite this version:}

Martine Naessens, Canh Tran-Minh. Biosensor using immobilized Chlorella microalgae for determination of volatile organic compounds.. Sensors and Actuators B: Chemical, 1999, 59 (1-2), pp.100-102. 10.1016/S0925-4005(99)00203-8 . emse-00494391

\section{HAL Id: emse-00494391 \\ https://hal-emse.ccsd.cnrs.fr/emse-00494391}

Submitted on 10 Jan 2011

HAL is a multi-disciplinary open access archive for the deposit and dissemination of scientific research documents, whether they are published or not. The documents may come from teaching and research institutions in France or abroad, or from public or private research centers.
L'archive ouverte pluridisciplinaire HAL, est destinée au dépôt et à la diffusion de documents scientifiques de niveau recherche, publiés ou non, émanant des établissements d'enseignement et de recherche français ou étrangers, des laboratoires publics ou privés. 


\title{
Biosensor using immobilized Chlorella microalgae for determination of volatile organic compounds
}

\author{
MARTINE NAESSENS (1), CANH TrANH MiNH(1)
}

(1) Ecole Nationale Supérieure des Mines de Saint Etienne, Centre SPIN ; Département

PMMC ; Equipe Génie Enzymatique, 158, Cours Fauriel ; 42023 Saint-Étienne Cedex 2, France

\begin{abstract}
A biosensor using Chlorella microalgae immobilized on the membrane of an oxygen electrode has been designed to determine volatile organic compounds (VOC) in the form of aerosols. A homemade controlled atmosphere chamber is constructed for perchloroethylene detection. Monitoring of perchloroethylene is obtained by the measurement of the oxygen production during the algae photosynthetic process.
\end{abstract}

Keywords:

Biosensor; Microalgae; Chlorella; Solvents; Aerosol; Volatile organic compounds

\section{Introduction}

The need for early-warning systems to detect toxic compounds is well established for the protection of the environment. The wide variety of chemical structures involved makes biological techniques more effective than physico-chemical methods to assess the toxicity of the various pollutants [1] and [2]. Biosensors operating in the workplace atmosphere can be used as a warning device so that immediate action can be taken to evacuate the workplace and to locate the source of release. However most biosensors using enzymes, immunoagents or microorganisms are effective in aqueous solutions [3], [4] and [5]. Our aim is to construct a biosensor capable to respond to a toxic volatile organic compound (VOC) such as perchloroethylene present in the form of aerosol. This VOC is often used in the form of vapour or aerosol for dry-cleaning and municipal treatment plant. It also affects the photosynthetic activity of Chlorella microalgae [6] which is then used as a bioreceptor immobilized on an oxygen electrode.

\section{Experimental}

The algal membrane is obtained from filtration of an algae suspension on a glass microfibre filter Whatman. The concentration of algae in suspension is previously determined by optical density (OD). A typical $10 \mathrm{ml}$ of a suspension of $\mathrm{OD}=0.34$ at $685 \mathrm{~nm}$ has been used for a 0.7 $\mathrm{cm}^{2}$ membrane. Algae were cultivated in our laboratory: the Chlorella vulgaris strain (CCAP 211/12) is purchased from The Culture Collection of Algae and Protozoa at Cumbria, UK.

The biosensor was constructed as previously described [7] from the combination of an algal membrane associated with an oxygen Clark electrode to measure the release of photosynthetic oxygen. This gas is produced from the photosynthetic activity of the microalgae under illumination conditions and in the presence of atmospheric carbon dioxide. Since the algal membrane is designed to work in the atmosphere, a water reservoir is fixed to the electrode body to provide humidity for the algal cells to operate properly (Figure 1).

An enclosed space is designed for aerosol detection. It consists of a homemade box which provides a $0.7 \mathrm{~m}^{3}$ controlled atmosphere chamber (Figure 2). The wall is covered with aluminium foil to prevent interfering light from outside. Temperature is maintained at $20^{\circ} \mathrm{C}$ and relative humidity at $75 \%$. The biosensor is placed in the box and connected to an oxygen measuring device outside the chamber. Periodical flashes of light are sent from a halogen light source (Schott KL 1500 Electronic $15 \mathrm{~V} / 150 \mathrm{~W}$ ) to the sensor through an optical fiber. Algae 
photosynthetic activity is measured during the illumination period and was recorded as a peak of oxygen production on the recorder chart. In the absence of aerosol, the peak of oxygen release, $\mathrm{H}_{0}$, is recorded and taken as a reference. When the toxic compound is sprayed in the controlled atmosphere chamber, the photosynthetic activity changes which modifies the release of oxygen and consequently the peak height. After the measurements, the toxic containing atmosphere is completely removed through a large flexible tube (inner diameter 0.1 $\mathrm{m})$ connected to an air pump.

\section{Results}

The method is based on the modification of the photosynthetic activity in the presence of the analyte used in the form of aerosols. This is the case of perchloroethylene. When perchloroethylene is sprayed into the chamber, the production of oxygen during the illumination period immediately changes and an increase $\Delta \mathrm{H}$ in peak height is immediately observed (Figure 3). Perchloroethylene is then an activator of the algal photosynthetic activity. During the first 30 min approximately, the oxygen peak heights increase linearly with time. The dynamic response is proportional to the concentration of perchloroethylene in the chamber if those concentrations do not exceed $250 \mathrm{ppm}$ (Figure 4). The dynamic response is defined as the ratio of the increase in peak heights to the time course:

dynamic response $=\Delta \mathrm{H} / \Delta \mathrm{t}$

with $\Delta \mathrm{H}=\mathrm{H}-\mathrm{H}_{0}, \Delta \mathrm{t}=\mathrm{t}-\mathrm{t}_{0}, \mathrm{H}_{\mathrm{o}}$ is the reference response and $\mathrm{t}_{\mathrm{o}}$ corresponds to the introduction of perchloroethylene. The dynamic response is then the change in oxygen production.

The response time can be assessed from the increase in the peak height after spraying perchloroethylene in the controlled atmosphere chamber. The perchloroethylene is sprayed immediately after the illumination period and the measurement is done after 5 -min darkness. Since the slope response is unchanged after this first period of time, it can be considered that the response time of the biosensor itself is less than $5 \mathrm{~min}$ for the tested concentrations (Figure 3). Preliminary assays show that the biosensor response depends on the thickness of the algal layer.

The dynamic response of the algal biosensor as a function of perchloroethylene concentrations is shown on Figure 4. The measurement is repeated three times for each concentration and the mean value is reported on the figure. The calibration curve can be considered as linear in the range of $0-250 \mathrm{ppm}$ of perchloroethylene. The straight line equation and the correlation coefficients shown on the graph are obtained with the least square method for six experimental points. The detection limit of the biosensor is dependent on the detection limit of the transducer which is the oxygen electrode. A concentration of $10 \mathrm{ppm}$ perchloroethylene corresponding to a signal-to-noise ratio of 3 , can be detected. As the limit value of workers exposure to perchloroethylene is $50 \mathrm{ppm}$ [8], this biosensor could be used as an early-warning device.

The recovering of the biosensor activity is dependent upon the exposure conditions. The biosensor is not reversible for perchloroethylene concentration higher than $340 \mathrm{ppm}$. A decrease in oxygen production during the photosynthetic process is observed day after day. Under the above mentioned conditions, and at room-temperature storage, about $50 \%$ of the algal activity in terms of oxygen production still remains on the membrane biosensor after 8 days. This could be improved by decreasing the light intensity which results in a longer response time.

\section{Conclusion}

For the first time, an algal biosensor has been constructed to operate in the gas phase for determination of aerosols. It allows direct determination in the gas phase without previous trapping the analyte in a solution. In addition, real-time monitoring is possible with continuous measurement of the algae photosynthetic activity by an oxygen electrode. Other toxic compounds (atrazine, paraquat or methanol...) which affect the algal photosynthetic 
activity can also be detected by this biosensor. Interference of other gaseous compounds is to be investigated.

\section{References}

[1] G. Bitton and B. Koopman, Bacterial and enzymatic bioassays for toxicity testing in the environment. Rev. Environ. Contam. Toxicol. 125 (1992), 1-22.

[2] K.R. Rogers, Biosensors for environmental applications. Biosens. Bioelectron. 10 (1995), 533-541.

[3] D.M. Rawson, A.J. Willmer and P.F. Turner, Whole-cell biosensors for environmental monitoring. Biosensors 4 (1989), 299-331.

[4] C. Tran-Minh, Biosensors, Chapman \& Hall, London, 1993.

[5] M. Koblizek, J. Masojidek, J. Komenda, T. Kucera, R. Pilloton, A.K. Mattoo and M.T. Giardi, A sensitive photosystem II based biosensor for detection of a class of herbicides. Biotechnol. Bioeng. 60 (1998), 664-669.

[6] P. Pandard, P. Vasseur and D.M. Rawson, Comparison of two types of sensors using eukaryotic algae to monitor pollution of aquatic systems. Water Res. 27 (1993), 427431.

[7] M. Naessens and C. Tran-Minh, Whole-cell biosensor for direct determination of solvent vapours. Biosens. Bioelectron. 13 (1998), 341-346.

[8] INRS Fiche toxicologique No. 29, INRS Paris (Ed.), 1997. 
Figures

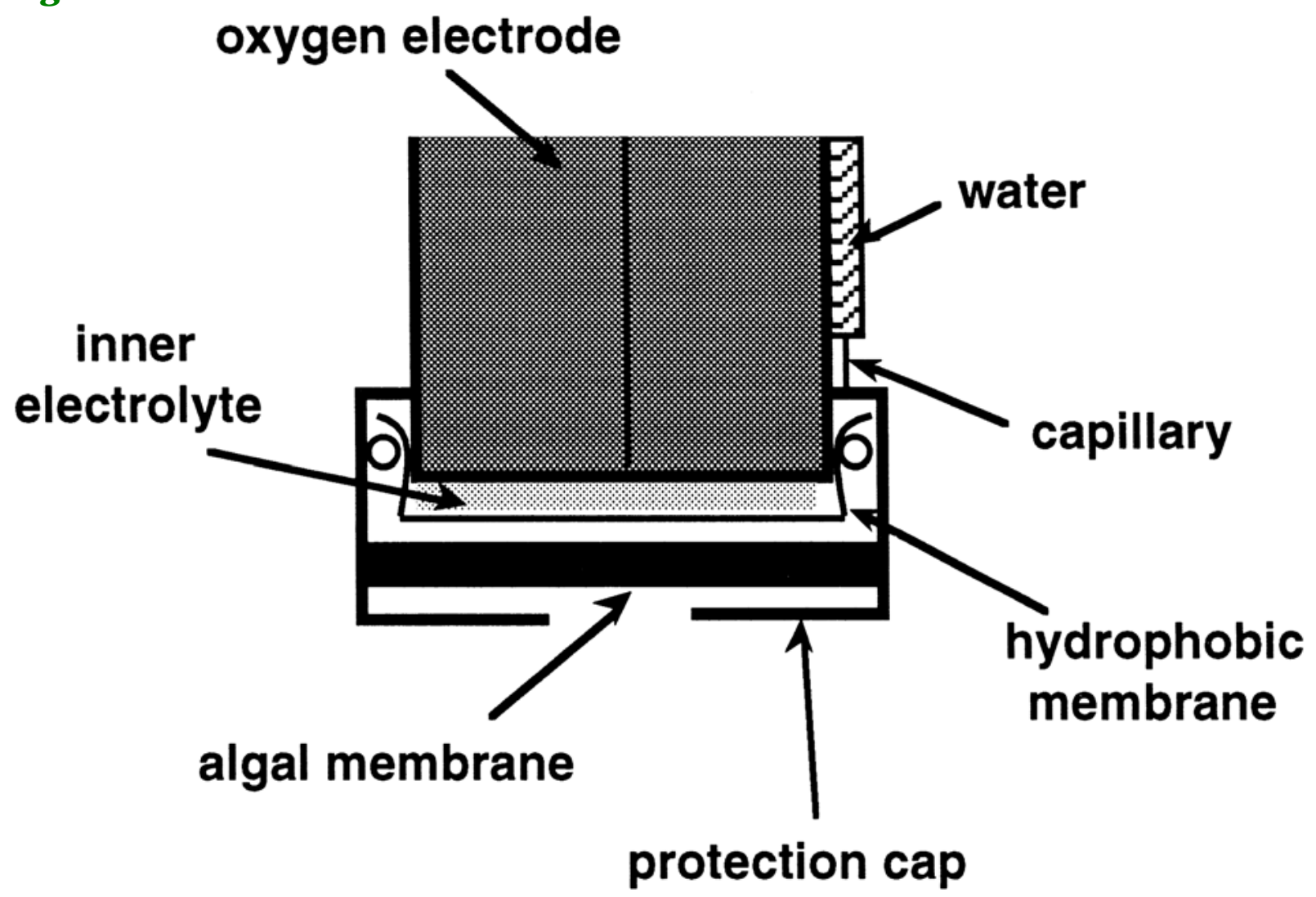

Figure 1: Algal biosensor using a $\mathrm{pO}_{2}$ electrode for direct determination of aerosols in atmosphere.

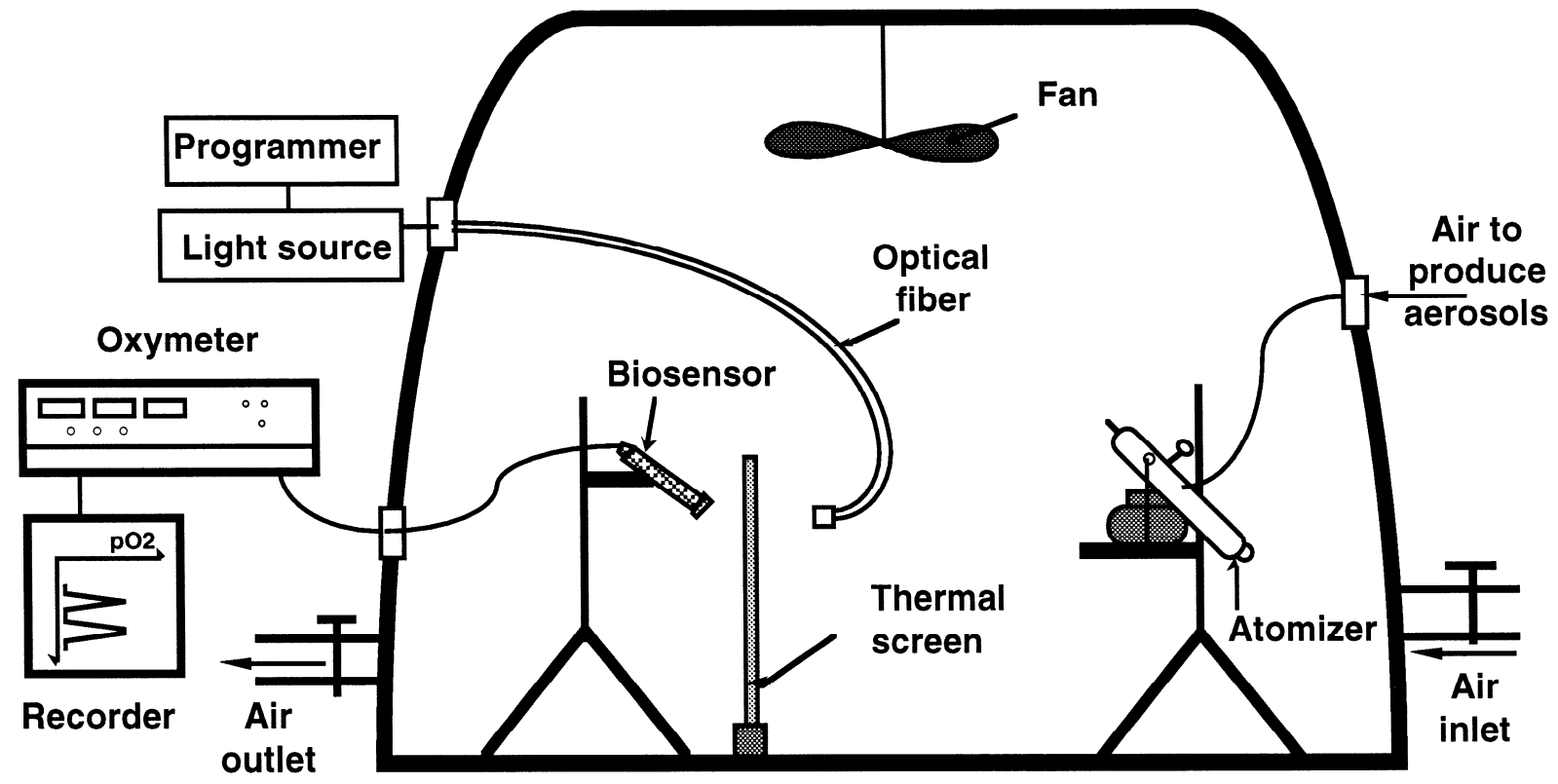

Figure 2: Controlled atmosphere chamber for determination of aerosols with an algal biosensor. 


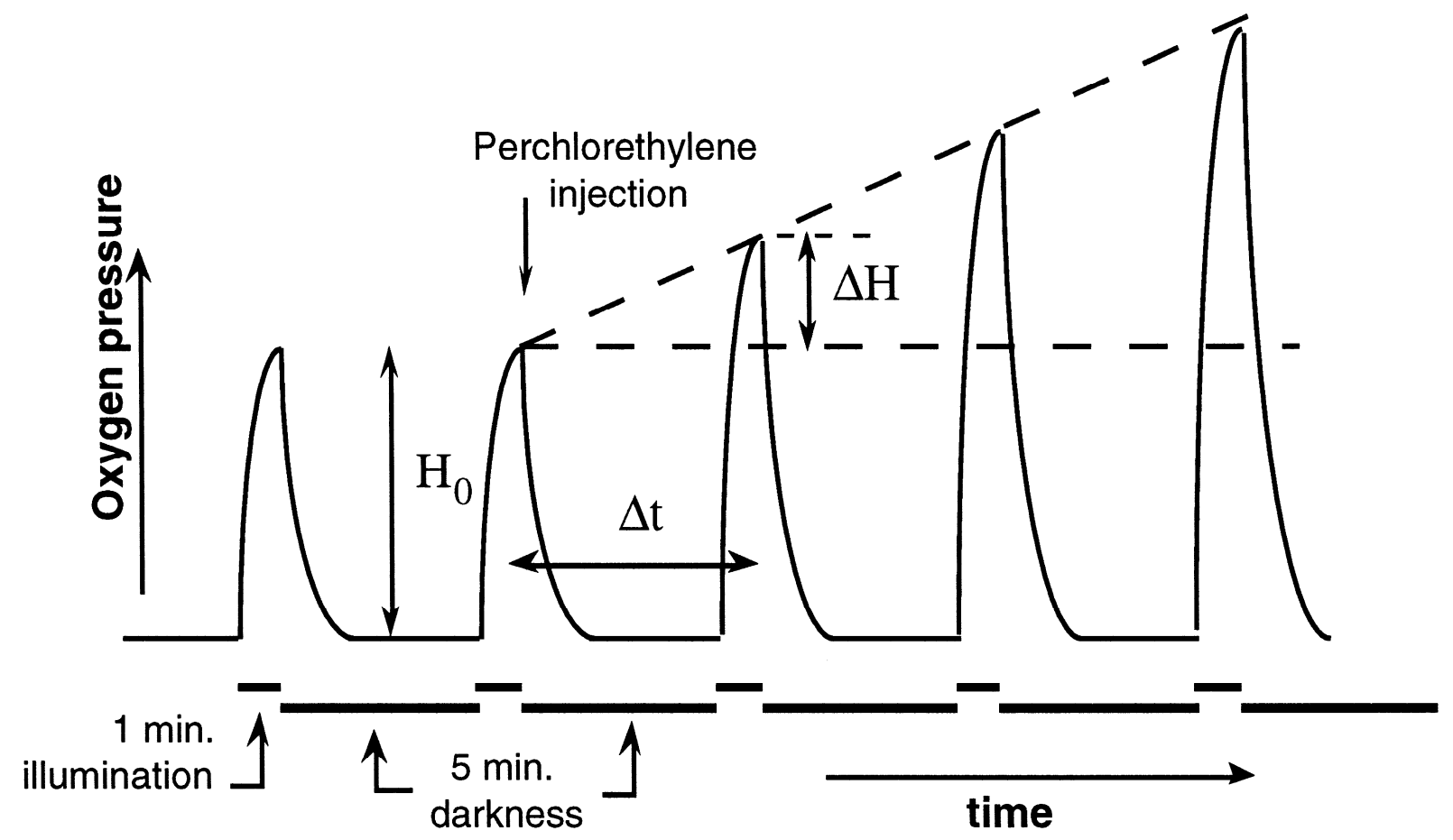

Figure 3: Typical responses of the algal biosensor to perchloroethylene aerosols.

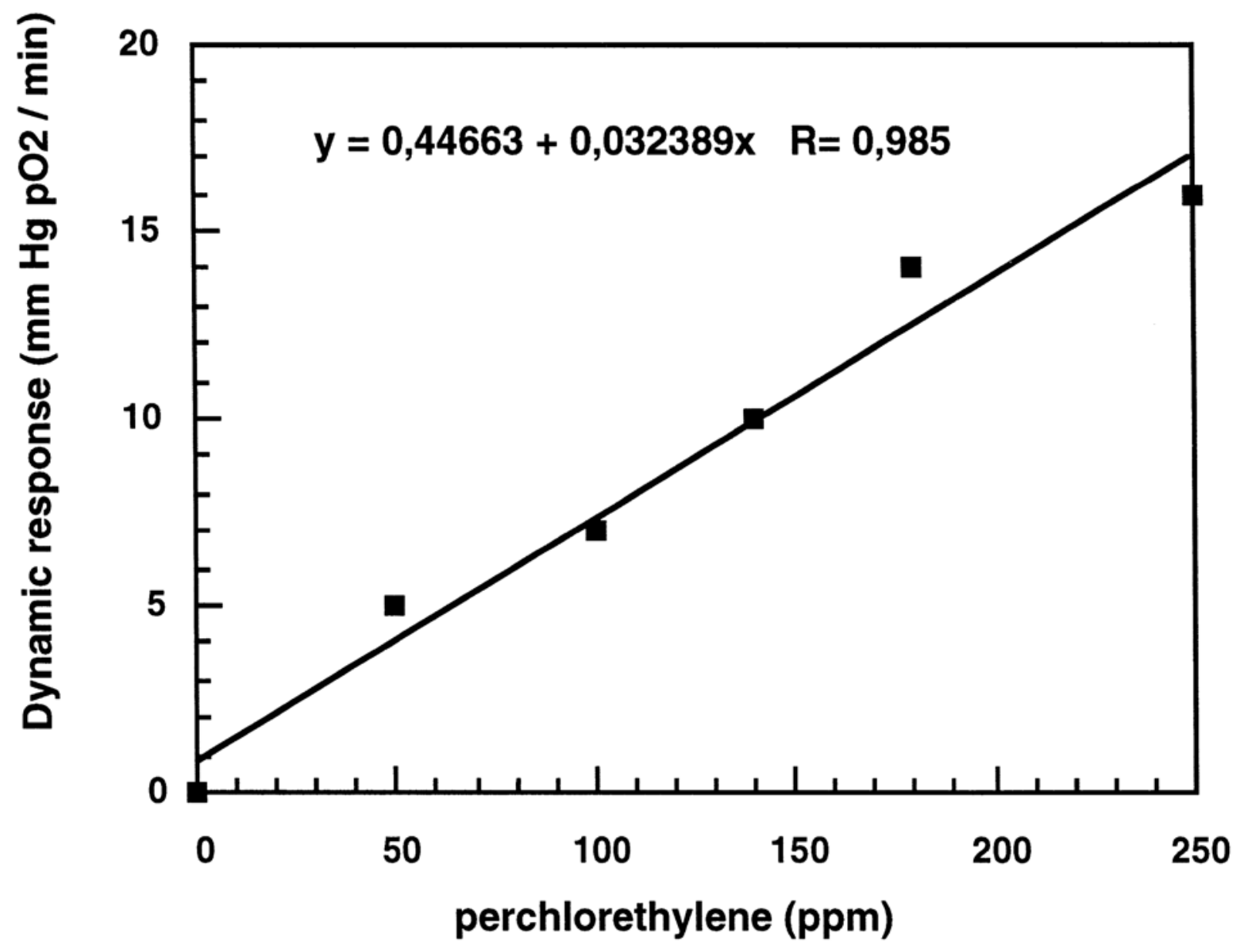

Figure 4: Dynamic response of the biosensor as a function of perchloroethylene concentration. 